\title{
Impact of EDTA, Citric Acid and Humic Acid on Phytoremedation of Metal Contaminated Soil by Indian Mustard (Brassica juncea) El-Agrodi, M. W. M. ${ }^{1}$; F. I. Zein ${ }^{2}$; G. Labeeb ${ }^{1}$ and M. S. A. Ramadan ${ }^{2}$ \\ ${ }^{1}$ Soils Dept. Fac. of Agric., Mansoura Univ., Egypt. \\ ${ }^{2}$ Soil, Water and Environment Res. Inst., A.R.C., Egypt.
}

\begin{abstract}
A pot experiment was conducted during winter season of (2013/2014) at Sakha Agricultural Research Station, Kafr ElSheikh Governorate. The experiment aimed to investigate the effect of disodium ethylenediaminetetraacetic acid (EDTA) (0.0, 1.5, 3.0 and $4.5 \mathrm{mmol} \mathrm{kg}^{-1}$ soil), citric acid (CA) $\left(0,3,6\right.$ and $9 \mathrm{mmol} \mathrm{kg}^{-1}$ soil) and humic acid (HA) $\left(0.0,0.2,0.4 \mathrm{and}_{0.6 \mathrm{~g} \mathrm{~kg}^{-1}}\right.$ soil) on the phytoextraction of $\mathrm{Cu}, \mathrm{Zn}$ and $\mathrm{Pb}$ from Al-Gabal Al-Asfar contaminated soil using indian mustard (Brassica juncea) and the leaching behavior of these metals from soil. The obtained results can be summarised in the following:- EDTA severely reduced indian mustard dry weight and visual symptoms of toxicity were observed, especially at 4.5 mmol EDTA kg-1 soil. Whilst, application of CA and HA ameliorated indian mustard growth.- EDTA was found to be the most efficient chelator in increasing concentrations of $\mathrm{Cu}$ and $\mathrm{Zn}$ in different indian mustard plant parts.- Increasing EDTA application rate up to $4.5 \mathrm{mmol}$ $\mathrm{kg}^{-1}$ soil increased the concentrations of $\mathrm{Cu}$ by $1.91,2.88,3.04$ and 1.56 folds and $\mathrm{Zn}$ by 1.43, 1.91, 1.83and 1.11 folds for roots, stem, leaves and seeds, respectively, compared to control treatment $\left(0.0 \mathrm{mmol}\right.$ EDTA kg ${ }^{-1}$ soil).- Application of CA also increased $\mathrm{Cu}$ and $\mathrm{Zn}$ concentrations by different indian mustard plant parts, especially at $9 \mathrm{mmol} \mathrm{\textrm {kg } ^ { - 1 }}$ soil, but its efficacy was less than EDTA.- HA application increased $\mathrm{Zn}$ concentrations in different indian mustard plant parts with increasing its addition up to $0.6 \mathrm{~g} \mathrm{~kg}^{-1}$ soil, but its efficacy was less than that of EDTA and CA.- HA application did not affect Cu concentrations in indian mustard.- There were neither any perceptible concentrations of $\mathrm{Pb}$ in different plant parts of indian mustard except for roots clarifying that phytoextraction of $\mathrm{Pb}$ failed even after application of tested chelators. - Application of EDTA and CA to the soil increased the leaching of $\mathrm{Cu}, \mathrm{Zn}$ and $\mathrm{Pb}$ under indian mustard cultivation with increasing application rate up to 4.5 and 9 mmol kg${ }^{-1}$ soil, respectively. However, the effect of EDTA was many times higher than that of CA. Whilst, HA application did not affect the leaching of studied metals.- Using $\mathrm{CA}$ for the phytoremediation of $\mathrm{Cu}$ and $\mathrm{CA}$ and $\mathrm{HA}$ for the phytoremediation of $\mathrm{Zn}$ is favorable than EDTA despite the high efficiency of EDTA, due to the harmful effects of EDTA on plant growth and the increased risk of groundwater contamination via metal leaching.
\end{abstract}

Keywords: phytoremediation, phytoextraction, $\mathrm{Zn}, \mathrm{Cu}, \mathrm{Pb}$ contaminated soils and indian mustard plant.

\section{INTRODUCTION}

Nowadays soil pollution is getting great public attention where the magnitude of this serious problem is growing rapidly. One of the most serious pollutants in the environment, especially agricultural environments, is heavy metals because of their elevated level of durability and toxicity to the biota (Alkorta et al., 2004). In Egypt, which located in arid and semi-arid regions, water is becoming scarce resource. Usage low quality water such as wastewater for irrigation causing soil pollution. Primary treated wastewater has been used in agriculture to irrigate about 1260 ha in Al Gabal Al Asfar since 1911 (Mahjoub, 2016).

The cleanup of contaminated soils is one of the most difficult tasks for environmental engineering, where, soil washing, excavation and land-filling can be used at highly contaminated sites but are not applicable to large areas and are very expensive. Immobilization of heavy metals has the advantage of immediately reducing risk of metals, but it considered as temporary alternative. Phytoremediation is a promising new approach, direct use of plants to clean up the soil from heavy metals in situ, friendly environment, economically cost-effective.

High-biomass and metal-hyper accumulator plant species have a high potential and promising to be used in phytoremediation, among them the Brassicaceae (mustard) family (Robinson et al., 2009).

Availability of heavy metals to plant roots is considered as key factor limiting the phytoextraction efficiency. In the last decade the use of persistent amino-polycarboxylic acids such as ethylene diaminetetraacetic acid (EDTA) was suggested as a chelating agent to assist the phytoextraction processes (Evangelou et al., 2007).Natural low molecular weight organic acids (LMWOA) such as citric acid (CA), oxalic acid, or malic acid play a significant role in heavy metal solubility (Nigam et al., 2001).Humic acids contain carboxylic groups which play a prominent role on heavy metals availability (Hofrichter and Steinbüchel, 2001). Zhang et al., (2003) stated that the lower stability constant of HA, compared to other synthetic chelates for metals, makes HA an ideal soil amendment for phytoextraction.

Therefore, the objectives of this study are to evaluate the efficiency of indian mustard (Brassica juncea) in phytoextraction of heavy metal from contaminated soil. Moreover, investigating the effect of synthetic and organic chelators on bioavailability and leachability of heavy metals.

\section{MATERIALS AND METHODS}

A pot experiment was conducted in a wired greenhouse at Sakha Agricultural Research Station, Kafr El-Sheikh Governorate during winter season of (2013/2014), aimed to investigate the phytoextraction efficiency of $\mathrm{Cu}, \mathrm{Zn}$ and $\mathrm{Pb}$ from Al-Gabal Al-Asfar contaminated soil using indian mustard (Brassica juncea) plant under chelators disodium ethylenediaminetetraacetic acid (EDTA), citric acid (CA) and humic acid (HA) addition.

Contaminated soil was collected from the surface layer $(0-30 \mathrm{~cm})$ of Al-Gabal Al-Asfar farm in 2013's early spring. Collected soil samples were air-dried, 
ground to pass through a $4 \mathrm{~mm}$ diameter sieve and mixed thoroughly to achieve homogeneity. Representative sample was ground to pass through a 2 $\mathrm{mm}$ sieve; some physical and chemical characteristics of the studied soil were determined and shown in Table (1).

Air-dried soil equivalent to $6.5 \mathrm{~kg}$ oven dry soil was placed in crockery pots $(25 \mathrm{~cm}$ diameter $\times 40 \mathrm{~cm}$ height) lined with polyethylene bags which were used to coat the inner walls of crockery pots in order to avoid water preferential flow. The polyethylene bags and pots were ended with a central hole at the bottom to collect the leached solution. A filter paper and a fine mesh tissue were used in order to prevent soil losses from the ended hole.

Table 1. Some physical and chemical characteristics of the tested soils.

\begin{tabular}{|c|c|c|}
\hline \multicolumn{3}{|l|}{ Soil characteristics } \\
\hline \multicolumn{2}{|l|}{ pH (soil-paste) } & 6.88 \\
\hline \multicolumn{2}{|l|}{$\mathrm{EC}_{\mathrm{e}}$ (soil-paste extract), $\mathrm{dSm}^{-1}$ at $25^{\circ} \mathrm{C}$} & 1.59 \\
\hline \multicolumn{2}{|l|}{ OM (organic matter), $\%$} & 2.03 \\
\hline \multicolumn{2}{|l|}{ Total carbonates, $\%$} & 0.22 \\
\hline \multicolumn{2}{|l|}{ Water holding capacity (WHC), \% } & 35.55 \\
\hline \multicolumn{2}{|c|}{ CEC (cation exchange capacity), meq/100g soil. } & 17.92 \\
\hline \multirow{3}{*}{ Particle size distribution } & Sand $(\%)$ & 82.55 \\
\hline & Silt (\%) & 5.02 \\
\hline & Clay $(\%)$ & 12.43 \\
\hline \multirow[t]{2}{*}{ Texture class } & & loamy sand \\
\hline & $\mathrm{Ca}^{++}$ & 5.19 \\
\hline \multirow{4}{*}{ Soluble cations $\left(\mathrm{meq} \mathrm{L}^{-1}\right)$} & $\mathrm{Mg}^{++}$ & 3.21 \\
\hline & $\mathrm{Na}^{+}$ & 6.37 \\
\hline & $\mathrm{K}^{+}$ & 0.63 \\
\hline & $\mathrm{CO}_{3}=$ & -- \\
\hline \multirow{4}{*}{ Soluble anions $\left(\right.$ meq $\left.\mathrm{L}^{-1}\right)$} & $\mathrm{HCO}_{3}^{-}$ & 6.88 \\
\hline & $\mathrm{Cl}^{-}$ & 5.76 \\
\hline & $\mathrm{SO}_{4}=$ & 2.76 \\
\hline & $\mathrm{N}$ & 35 \\
\hline \multirow[t]{3}{*}{ Available Macro-nutrients $\left(\mathrm{mg} \mathrm{kg}^{-1}\right)$} & $\mathrm{P}$ & 44.39 \\
\hline & $\mathrm{K}$ & 147.50 \\
\hline & $\mathrm{Pb}$ & 36.00 \\
\hline \multirow[t]{3}{*}{ DTPA-extractable $\left(\mathrm{mg} \mathrm{kg}^{-1}\right)$} & $\mathrm{Cu}$ & 27.00 \\
\hline & $\mathrm{Zn}$ & 67.00 \\
\hline & $\mathrm{Pb}$ & 210.00 \\
\hline \multirow[t]{2}{*}{ Total $\left(\mathrm{mg} \mathrm{kg}^{-1}\right)$} & $\mathrm{Cu}$ & 107.00 \\
\hline & $\mathrm{Zn}$ & 380.00 \\
\hline
\end{tabular}

The experiment was done under natural daylight in a wired greenhouse. Split plot design with three replicates was used. The main plots were assigned to chelator type, whereas, the sub-plots were subjected to chelator addition rates $\left(\mathrm{C}_{0}, \mathrm{C}_{1}, \mathrm{C}_{2}\right.$ and $\left.\mathrm{C}_{3}\right)$ as following:

(i) $\operatorname{EDTA}\left(0.0,1.5,3.0\right.$ and $4.5 \mathrm{mmol} \mathrm{kg}{ }^{-1}$ soil)

(ii) $\mathrm{CA}\left(0.0,3,6\right.$ and $9 \mathrm{mmol} \mathrm{kg} \mathrm{m}^{-1}$ soil $)$

(iii) $\mathrm{HA}\left(0.0,0.2,0.4\right.$ and $0.6 \mathrm{~g} \mathrm{~kg}^{-1}$ soil)

Four seeds of indian mustard plant were sown on October $20^{\text {th }}$, 2013. At fourth plant leaf stage, plants were thinned to one plant per pot. The irrigation water was added to all plants as needed in the beginning. After chelators addition, the irrigation water was added at $100 \%$ of water holding capacity (WHC) plus $5 \%$ in order to receive the leachate. NPK fertilization was done as 2.0 fold of Egyptian Ministry of Agriculture recommendation (Potassium fertilizer $25 \mathrm{~kg} \mathrm{~K}_{2} \mathrm{O}$ fed $^{-1}$ was applied in the form of potassium sulphate, phosphorus fertilizer $30 \mathrm{~kg}\left(\mathrm{P}_{2} \mathrm{O}_{5}\right) \mathrm{fed}^{-1}$ was applied in the form of phosphoric acid, and nitrogen fertilizer 45 $\mathrm{kg}(\mathrm{N}) \mathrm{fed}^{-1}$ was applied in the form of Urea).
Chelating agents with selected levels were added to the soil on two equal doses with irrigation water through rapid growth stage. The first dose was added 45 days of cultivation of indian mustard plant and the second dose was added after 30 days of the first dose.

The leachate solutions collection was started from the bottom of each pot after addition of chelating agents up to the end of growing seasons.

Dropped leaves of each plant were collected during growing season. On $20^{\text {th }}$ of March (2014), full maturity stage, plants were totally removed from pots and plant organs were separated to roots, stem, leaves and seeds.

\section{Method of analysis:}

\section{Soil analysis}

- Soil reaction (pH), Electrical conductivity (ECe) and soluble cations and anions according to Page (1982).

- Total organic matter (OM) was determined by the wet combustion of Walkely-Black method (Hesse, 1971).

- Available N, P, K and cation exchange capacity were determined according to Jackson (1973).

- Soil mechanical analysis was determined according to the international pipette method (Piper, 1950).

- Total $\mathrm{CaCO}_{3} \%$ was measured volumetrically by Collins calcimeter and water holding capacity (WHC) was measured according to Richards (1954).

- Available contents of heavy metals were extracted by diethylenetriaminepentaacetic acid (DTPA) (Lindsay and Norvell, 1978).

- Total contents of heavy metals were determined using aqua regia digestion according to Cottenie et al., (1982).

- Heavy metals were measured using the Atomic Absorption Spectrophotometer (AAS), PERKIN ELMER 3300.

- The collected leachate solutions were filtered through Whatman No. 42 filter paper and analyzed for heavy metals using (AAS), PERKIN ELMER 3300.

Plant analysis

- Separated plant parts were gently brushed using a brush pen, washed with tap water then distilled water three times, oven dried at $70{ }^{\circ} \mathrm{C}$ for $72 \mathrm{~h}$, weighed, milled in a stainless steel mill, finally analyzed for heavy metals using (AAS), PERKIN ELMER 3300, after wet digestion by $\left(\mathrm{HNO}_{3} / \mathrm{HClO}_{4}\right)$ mixture according to Chapman and Pratt (1961).

All collected data were statistically analyzed according to the method described by Snedecor and Cochran (1980) using the CoStat package program, version 6.311 (cohort software, USA). To compare between treatment means, the Least Significant Differences (LSD) at probability 5\% was used.

\section{RESULTS AND DISCUSSION}

\section{Effect of chelator types, rates and their interaction on indian mustard dry weight ( $\left(\right.$ plant $\left.^{-1}\right)$ :}

Data of Table (2) represent the effect of chelator types, rates and their interaction on indian mustard roots, stem, leaves, seeds and total dry weight 
production. Data reveal that chelator types significantly affected the dry weight of indian mustard different plant parts. All plant parts recorded the highest values due to HA application. EDTA reduced plant organs dry weight to a large extent compared with CA and HA.

In this respect, application of HA increased the mean values of roots, stem, leaves, seeds and total dry weight as compared to the mean values of EDTA by $18.80,15.41,17.42,16.22$ and $16.63 \%$, respectively. Whilst, CA treatment increased the mean values of root, stem, leaves, seeds and total dry weight by $15.79,10.61$,
$16.67,10.81$ and $12.89 \%$, respectively, as compared to EDTA means.

Application of EDTA levels significantly reduced indian mustard dry weight yield as compared to control, 0.0 EDTA. Moreover, the reduction was increased with increasing EDTA application rate up to $4.5 \mathrm{mmol} \mathrm{kg}^{-1}$ soil. The reduction in roots, stem, leaves, seeds and total dry weight as a result of applying EDTA at a rate of 4.5

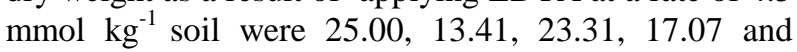
$18.09 \%$, respectively, as compared to control.

Table 2. Effect of chelator types, rates and their interaction on plant parts dry weight (g plant $\left.{ }^{-1}\right)$ of indian $^{-1}$ mustard.

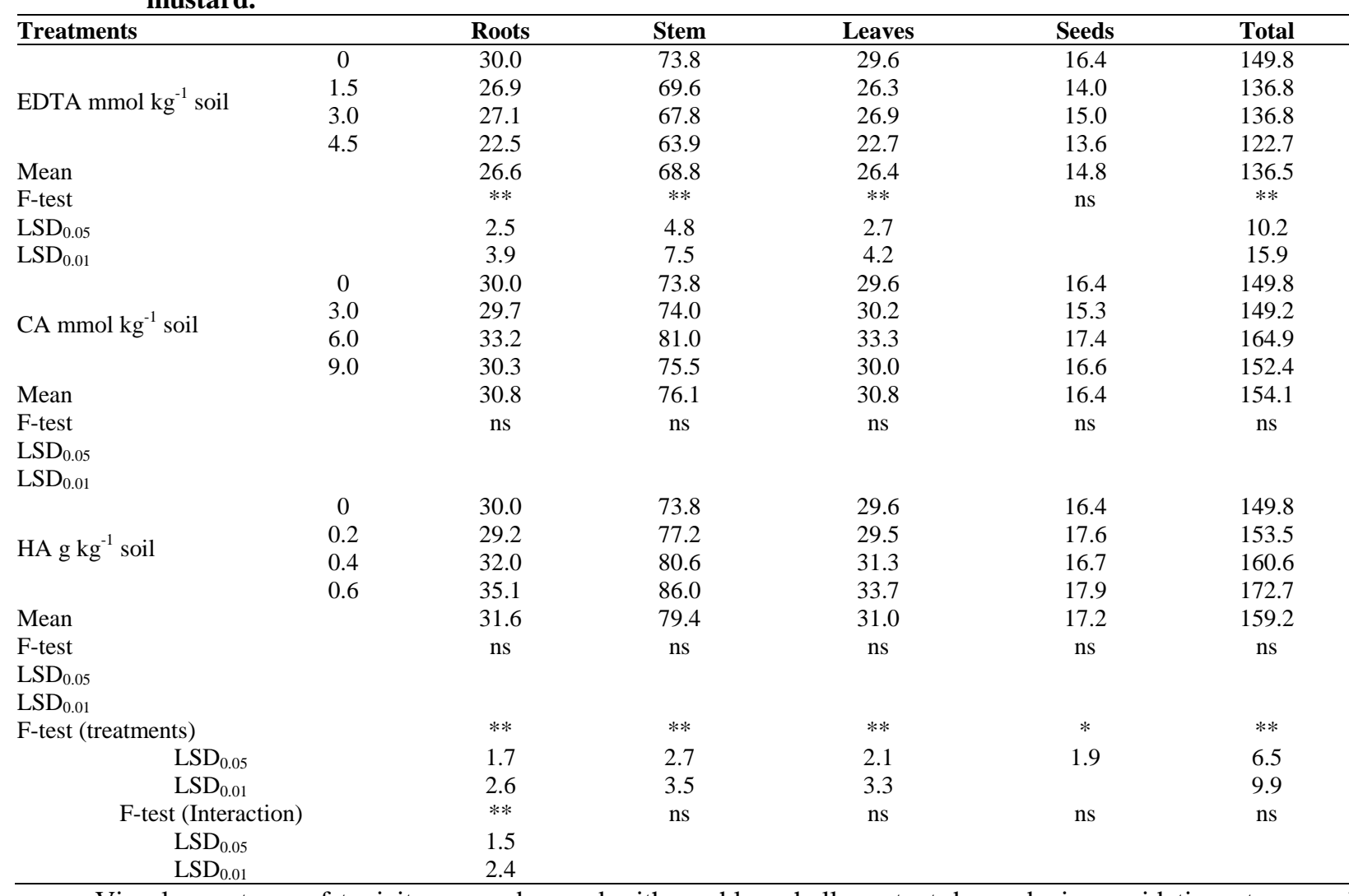

Visual symptoms of toxicity were observed with EDTA treatment, especially at high level $\left(4.5 \mathrm{mmol} \mathrm{kg}^{-1}\right.$ soil), as shown in (fig. 1), such as some chlorosis and necrosis (brown dots) on leaves, particularly on old ones, and the leave became yellow and died slowly. Similar results were found by Taalab et al., (2009). This could be attributed to either increasing EDTA itself and its metal complexes in root media as suggested by Chen and Cutright (2001) or heavy metal accumulation in plant parts causing toxicity as discussed later.

Regarding the effect of $\mathrm{CA}$ application rates, increasing CA applied rate up to $6.0 \mathrm{mmol} \mathrm{kg}{ }^{-1}$ soil in Al-Gabal Al-Asfar soil increased plant organs and totaldry weight but the increment values in each trait was insignificant. However, the corresponding values for roots, stem, leaves and seeds were increased by $10.67,9.76,12.50,6.10$ and $10.08 \%$ compared with control. These increases in plant growth and biomass might be due to increased nutrient uptake and CAinduced chelation of metals decreasing free metal ions in plants as suggested by Najeeb et al., (2011). CA application increased plant growth, biomass, and chlorophyll content by reducing oxidative stress and enhancing antioxidant enzyme activities (Zaheer et al., 2015).

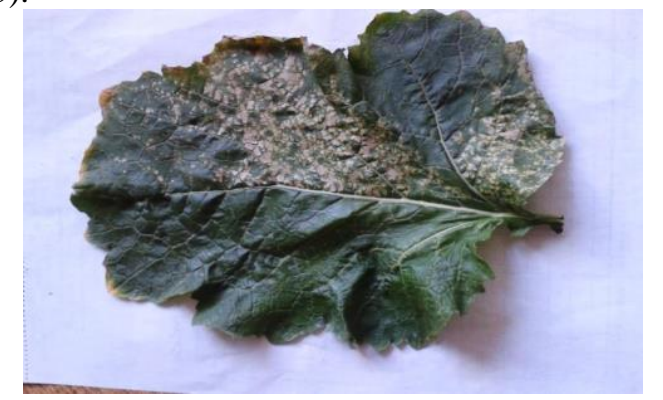

Fig 1. visual symptoms of toxicity on indian mustard leaves due to application of 4.5 mmol EDTA $\mathrm{kg}^{-1}$ soil.

Increasing HA applied rates increased plant dry weight, but this increase was insignificant as a result of their non-significant effects on plant organs dry weight. The highest level used of HA ( $0.6 \mathrm{~g} \mathrm{HA} \mathrm{kg}^{-1}$ soil) recorded the highest values of plant parts dry weight as compared to control, where the increment values of 
roots, stem, leaves, seeds and total dry weight were $17.00,16.53,13.85,8.9 .15$ and $15.29 \%$ as compared to control.

Data of Table (2) illustrate that no significant effects were found due to the interaction between chelator types and addition rates on plant dry weight, except for roots where applying $0.6 \mathrm{~g} \mathrm{HA} \mathrm{kg}^{-1}$ soil achieved the highest roots dry weight, $35.10 \mathrm{~g}$.

Effect of chelator types, rates and their interaction on $\mathrm{Cu}$ concentration $\left(\mathrm{mg} \mathrm{kg}^{-1} \mathrm{DW}\right)$ of indian mustard plant:

Data of Table (3) show the effect of chelator types, rates and their interaction on $\mathrm{Cu}$ concentrations of roots, stem, leaves and seeds.

Regarding chelator types effect, results reveal that applied chelators significantly affect $\mathrm{Cu}$

Table 3. Effect of chelator types, rates and their interaction on $\mathrm{Cu}$ concentration $\left(\mathrm{mg} \mathrm{kg}^{-1}\right)$ of roots, stem, leaves and seeds of indian mustard.

\begin{tabular}{|c|c|c|c|c|c|}
\hline \multicolumn{2}{|l|}{ Treatments } & Roots & Stem & Leaves & Seeds \\
\hline & 0 & 163.3 & 20.8 & 20.0 & 13.3 \\
\hline EDTA mmol kg ${ }^{-1}$ & 1.5 & 202.5 & 31.7 & 35.8 & 15.8 \\
\hline \multirow[t]{2}{*}{ soil } & 3.0 & 251.7 & 50.8 & 48.3 & 17.5 \\
\hline & 4.5 & 312.5 & 60.0 & 60.8 & 20.8 \\
\hline \multicolumn{2}{|l|}{ Mean } & 232.5 & 40.8 & 41.2 & 16.9 \\
\hline \multicolumn{2}{|l|}{ F-test } & $* *$ & $* *$ & $* *$ & $* *$ \\
\hline \multicolumn{2}{|l|}{$\mathrm{LSD}_{0.05}$} & 12.8 & 3.3 & 4.2 & 2.7 \\
\hline \multicolumn{2}{|l|}{$\operatorname{LSD}_{0.01}$} & 20.0 & 5.1 & 6.6 & 4.2 \\
\hline \multirow{4}{*}{ CA mmol kg-1 soil } & 0 & 163.3 & 20.8 & 20.0 & 13.3 \\
\hline & 3.0 & 174.2 & 27.5 & 26.7 & 11.7 \\
\hline & 6.0 & 202.5 & 33.3 & 31.7 & 11.7 \\
\hline & 9.0 & 255.8 & 40.0 & 38.3 & 14.2 \\
\hline \multicolumn{2}{|l|}{ Mean } & 199.0 & 30.4 & 29.2 & 12.7 \\
\hline \multicolumn{2}{|l|}{ F-test } & ** & ** & ** & $\mathrm{ns}$ \\
\hline \multicolumn{2}{|l|}{$\mathrm{LSD}_{0.05}$} & 11.7 & 4.5 & 4.7 & \\
\hline \multicolumn{2}{|l|}{$\operatorname{LSD}_{0.01}$} & 18.2 & 7.0 & 7.2 & \\
\hline \multirow{4}{*}{$\mathrm{HA} \mathrm{g} \mathrm{kg}^{-1}$ soil } & 0 & 163.3 & 20.8 & 20.0 & 13.3 \\
\hline & 0.2 & 169.2 & 20.8 & 20.8 & 11.7 \\
\hline & 0.4 & 156.7 & 20.8 & 18.3 & 11.7 \\
\hline & 0.6 & 144.2 & 19.2 & 19.2 & 12.5 \\
\hline \multicolumn{2}{|l|}{ Mean } & 158.3 & 20.4 & 19.6 & 12.3 \\
\hline \multicolumn{2}{|l|}{ F-test } & * & $\mathrm{ns}$ & $\mathrm{ns}$ & $\mathrm{ns}$ \\
\hline \multicolumn{2}{|l|}{$\mathrm{LSD}_{0.05}$} & 19.2 & & & \\
\hline \multicolumn{6}{|l|}{$\mathrm{LSD}_{0.01}$} \\
\hline \multicolumn{2}{|l|}{ F-test (treatments) } & $* *$ & $* *$ & ** & $* *$ \\
\hline \multicolumn{2}{|l|}{$\mathrm{LSD}_{0.05}$} & 9.8 & 3.3 & 4.9 & 2.1 \\
\hline \multicolumn{2}{|l|}{$\mathrm{LSD}_{0.01}$} & 14.9 & 5.0 & 7.5 & 3.2 \\
\hline \multicolumn{2}{|l|}{ F-test (Interaction) } & $* *$ & $* *$ & $* *$ & ns \\
\hline \multicolumn{2}{|l|}{$\mathrm{LSD}_{0.05}$} & 8.5 & 2.8 & 4.3 & \\
\hline \multicolumn{2}{|l|}{$\mathrm{LSD}_{0.01}$} & 12.9 & 4.3 & 6.5 & \\
\hline
\end{tabular}

Regarding chelator rates effect, increasing of EDTA levels up to $4.5 \mathrm{mmol} \mathrm{kg}{ }^{-1}$ soil high significantly increased $\mathrm{Cu}$ concentration in roots, stem, leaves and seeds by $1.91,2.88,3.04$ and 1.56 folds compared to control, respectively. Similar trend was found by $\mathrm{Wu}$ et al., (2004), where 3 mmol EDTA kg-1 soil elevated $\mathrm{Cu}$ concentration from 15.3 to $39.8 \mathrm{mg} \mathrm{kg}^{-1}$ in indian mustard plant grown on a paddy soil polluted with $\mathrm{Cu}$. The neutral charge, metal-EDTA complex are not blocked or attached by carboxyl groups or polysaccharides of rhizoderm cell surface. In this way, EDTA causes the metal to enter directly to the plant roots (Shahid et al., 2012).

In case of CA, similar trend to EDTA was found, where $\mathrm{Cu}$ concentrations in roots, stem and leaves were significantly increased with increasing CA application levels up to $9 \mathrm{mmol} \mathrm{kg}{ }^{-1}$ soil. While no significant effect highest $\mathrm{Cu}$ concentration of indian mustard plant parts. $\mathrm{HA}$ application recorded the lowest $\mathrm{Cu}$ concentration in plant parts. In this respect, the concentrations of $\mathrm{Cu}$ in roots, stem, leaves and seeds was increased due to EDTA application compared to HA by $46.78,100.00$, 110.20 and $37.40 \%$, respectively. Whereas, CA treatment increased that trait of roots, stem, leaves and seeds compared to HA by 25.71, 49.02, 48.98 and $3.25 \%$, respectively. The high efficacy of EDTA could be attributed to that addition of EDTA to soil transfers metal sorption and precipitation equilibrium toward enhanced heavy metals dissolution due to forming metal-EDTA complexes as reported by Hadi et al., (2010).

on $\mathrm{Cu}$ concnetrations in seeds was found due to application of different CA levels. In this respect, the values of $\mathrm{Cu}$ concentration in roots, stem and leaves increased as compared with control by 1.57, 1.92 and 1.92 folds, respectively, when CA was applied at a level of $9 \mathrm{mmol} \mathrm{kg}^{-1}$ soil. These results are in harmony with that of Evangelou et al., (2006) who revealed that application of $62.5 \mathrm{mmol} \mathrm{kg}{ }^{-1} \mathrm{CA}$ had 2-folds increase of $\mathrm{Cu}$ concentrations in tobacco ( $N$. tabacum) shoots. Also, Zaheeret al., (2015) found that addition of CA increased $\mathrm{Cu}$ uptake by $B$. napus plants and the negative effects of $\mathrm{Cu}$ toxicity can be overturned by $\mathrm{CA}$ application.

Concerning the effect of $\mathrm{HA}$ on $\mathrm{Cu}$ concentrations of indian mustard plant, the obtained results point out that different applied rates of $\mathrm{HA}$ decreased concentrations of $\mathrm{Cu}$ in plant parts. However, concentrations in plant parts. Where, EDTA gave the 
this decrease in $\mathrm{Cu}$ concentration in indian mustard was insignificant, except for roots was significant. The highest reduction of $\mathrm{Cu}$ concentrations in roots and stem (mg kg ${ }^{-1} \mathrm{DW}$ ) were obtained using $0.6 \mathrm{~g} \mathrm{HA} \mathrm{kg}^{-1}$ soil and the corresponding reductions were 11.69 and $7.69 \%$ as compared to control, respectively. While application of $0.4 \mathrm{~g} \mathrm{HA} \mathrm{kg}^{-1}$ soil achieved the highest reduction of $\mathrm{Cu}$ concentration in leaves and seeds and these reductions were amounted by 8.50 and $12.03 \%$ as compared to control, respectively. These results are in parallel trend with that of Wang et al., (2010). They found that increasing HA addition from 3.09 to $7.89 \mathrm{~g}$ $\mathrm{kg}^{-1}$ soil to $\mathrm{Cu}$ and $\mathrm{Cd}$ contaminated sediment reduced $\mathrm{Cd}$ concentrations in Vallisneria spiralis roots and shoots by $26.4-50.3 \%$ and $14.3-33.0 \%$, whereas, $\mathrm{Cu}$ accumulation was decreased much more with 44.0 $77.0 \%$ and $35.0-62.7 \%$, respectively. Humic acid clearly reduced $\mathrm{Cu}$ and $\mathrm{Cd}$ bioavailability and toxicity in $V$. speralis due to forming complexes of HA with metal ions.

Regarding the interaction between chelator types and their addition rates, significant effects on $\mathrm{Cu}$ concentration $\left(\mathrm{mg} \mathrm{kg}^{-1}\right)$ in roots, stem, leaves and seeds were found. While no significant effect on $\mathrm{Cu}$ concentrations in seeds was found. However, application of $4.5 \mathrm{mmol}$ EDTA $\mathrm{kg}^{-1}$ soil achieved the highest concentrations of $\mathrm{Cu}$ in plant organs.

Effect of chelator types, rates and their interaction on $\mathrm{Zn}$ concentration $\left(\mathrm{mg} \mathrm{kg}^{-1} \mathrm{DW}\right)$ of indian mustard plant:

Data in Table (4) represent the effect of chelator type, rates and their interaction on $\mathrm{Zn}$ concentrations of roots, stem, leaves and seeds of indian mustard.

Concerning the effect of chelator types used, it was noticed that $\mathrm{Zn}$ concentrations in different plant parts were significantly differed due to chelators types application. In this respect, EDTA increased roots, stem, leaves and seeds $\mathrm{Zn}$ concentration $\left(\mathrm{mg} \mathrm{kg}^{-1} \mathrm{DW}\right)$ as compared to HA by $14.90,37.59,18.25$ and $4.11 \%$, respectively. Whereas, application of $\mathrm{CA}$ treatment increased the mean values of $\mathrm{Zn}$ concentration $\left(\mathrm{mg} \mathrm{kg}^{-}\right.$ $\left.{ }^{1} \mathrm{DW}\right)$ in roots, stem, leaves and seeds by $5.24,8.69$, 1.67 and $11.92 \%$ as compared to HA, respectively.

Table 4. Effect of chelator types, rates and their interaction on $\mathrm{Zn}$ concentration $\left(\mathrm{mg} \mathrm{kg}^{-1} \mathrm{DW}\right)$ of roots, stem, leaves and seeds of indian mustard.

\begin{tabular}{|c|c|c|c|c|c|}
\hline Treatments & & roots & stem & leaves & seeds \\
\hline & 0 & 533.3 & 127.5 & 235.8 & 74.2 \\
\hline EDTA mmol kg-1 & 1.5 & 580.8 & 170.0 & 280.0 & 78.3 \\
\hline \multirow[t]{2}{*}{ soil } & 3.0 & 691.7 & 200.0 & 325.0 & 79.2 \\
\hline & 4.5 & 764.2 & 243.3 & 431.7 & 82.5 \\
\hline Mean & & 642.5 & 185.2 & 318.1 & 78.6 \\
\hline F-test & & $* *$ & $* *$ & $* *$ & ns \\
\hline $\mathrm{LSD}_{0.05}$ & & 24.5 & 16.1 & 19.0 & \\
\hline $\mathrm{LSD}_{0.01}$ & & 38.1 & 25.1 & 29.7 & \\
\hline \multirow{4}{*}{ CA mmol kg ${ }^{-1}$ soil } & 0 & 533.3 & 127.5 & 235.8 & 74.2 \\
\hline & 3.0 & 560.8 & 138.3 & 253.3 & 78.2 \\
\hline & 6.0 & 602.5 & 152.5 & 280.0 & 85.8 \\
\hline & 9.0 & 657.5 & 166.7 & 325.0 & 99.9 \\
\hline Mean & & 588.5 & 146.3 & 273.5 & 84.5 \\
\hline F-test & & $* *$ & $* *$ & $* *$ & $* *$ \\
\hline $\mathrm{LSD}_{0.05}$ & & 20.9 & 14.2 & 15.6 & 9.5 \\
\hline $\mathrm{LSD}_{0.01}$ & & 32.6 & 22.1 & 24.3 & 14.7 \\
\hline \multirow{4}{*}{$\mathrm{HA} \mathrm{g} \mathrm{kg}^{-1}$ soil } & 0 & 533.3 & 127.5 & 235.8 & 74.2 \\
\hline & 0.2 & 544.2 & 128.3 & 255.0 & 77.3 \\
\hline & 0.4 & 560.8 & 134.2 & 270.8 & 75.0 \\
\hline & 0.6 & 598.3 & 148.3 & 314.2 & 75.3 \\
\hline Mean & & 559.2 & 134.6 & 269.0 & 75.5 \\
\hline F-test & & $* *$ & $* *$ & $* *$ & ns \\
\hline $\mathrm{LSD}_{0.05}$ & & 21.0 & 7.8 & 23.7 & \\
\hline $\mathrm{LSD}_{0.01}$ & & 32.7 & 12.2 & 36.9 & \\
\hline F-test (treatments) & & $* *$ & $* *$ & $* *$ & $*$ \\
\hline $\mathrm{LSD}_{0.05}$ & & 16.9 & 8.4 & 16.2 & 8.2 \\
\hline $\mathrm{LSD}_{0.01}$ & & 25.6 & 12.7 & 24.5 & \\
\hline F-test (Interaction) & & $* *$ & $* *$ & $* *$ & $* *$ \\
\hline $\mathrm{LSD}_{0.05}$ & & 14.6 & 7.3 & 14.0 & 7.1 \\
\hline $\mathrm{LSD}_{0.01}$ & & 22.1 & 11.0 & 21.3 & 10.8 \\
\hline
\end{tabular}

Tabulated data show that $\mathrm{Zn}$ concentration of each plant part was significantly increased with increasing EDTA addition rate up to $4.5 \mathrm{mmol} \mathrm{kg}{ }^{-1}$ soil, except for seeds where the increases in $\mathrm{Zn}$ concentrations were insignificant. Accordingly, addition of 4.5 mmol EDTA kg-1 soil significantly increased $\mathrm{Zn}$ concentrations in roots, stem and leaves by $43.30,90.82$ and $83.08 \%$ as compared to control, respectively. The concentrations of $\mathrm{Zn}$ in seeds was insignificantly increased with increasing EDTA levels up to $4.5 \mathrm{mmol}$ $\mathrm{kg}^{-1}$ soil by $11.19 \%$ increase compared to control.
Increasing Zn concentration of plant parts with EDTA application is a normal result due to its effect on $\mathrm{Zn}$ availability in soil. These results are in a consistency with that of $\mathrm{Wu}$ et al., (2003) who outlined that $3 \mathrm{mmol}$ EDTA $\mathrm{kg}^{-1}$ soil increased $\mathrm{Zn}$ concentration in soil solution.

In case of $\mathrm{CA}$, the obtained results also reveal that $\mathrm{Zn}$ concentrations in indian mustard plants parts were increased by increasing CA levels up to $9 \mathrm{mmol}$ $\mathrm{kg}^{-1}$ soil. Accordingly, application of $9.0 \mathrm{mmol} \mathrm{CA} \mathrm{kg}{ }^{-1}$ soil significantly increased $\mathrm{Zn}$ concentrations in roots, 
stem, leaves and seeds as compared to control by 1.23 , $1.31,1.38$ and 1.35 folds, respectively. These results are in harmony with those of Najeeb et al., (2009). They stated that CA induced chelation of metals decreasing free ions in plant, hence CA promote plant for more metal uptake with no negative effect.

Regarding to HA, application at different levels revealed significant increases in different plant parts, except for seeds. Application of $0.6 \mathrm{~g} \mathrm{HA} \mathrm{kg}^{-1}$ soil achieved the highest values of $\mathrm{Zn}$ concentrations in roots, stem and leaves as compared to control and lower HA application levels. The corresponding increases for roots, stem and leaves were increased as compared to control by $12,19,16.31$ and $33.25 \%$, respectively. A parallel results were found by Turan and Angin (2004),they found that HA (at rates of 5 and $10 \mathrm{mmol}$ $\mathrm{kg}^{-1}$ soil) was effective natural chelator in enhancing $\mathrm{Pb}$, $\mathrm{Cd}$, Mo and B desorption from soil and increasing their accumulation in Zea mays L. and Helianthus annus L. Also, Topcuoğlu (2012) found that the availability and uptake of $\mathrm{Zn}$ by tobacco plant was significantly raised by $\mathrm{HA}$ application at $1 \%$ and $2 \%$.

In respect to the interaction between chelator types and their addition rates, a significant effect on roots, stem, leaves, seeds and total uptake of $\mathrm{Zn}(\mathrm{mg} \mathrm{kg}$ $\left.{ }^{1}\right)$ by indian mustard were found. Whereas, application of $4.5 \mathrm{mmol}$ EDTA $\mathrm{kg}^{-1}$ soil revealed the highest concentrations of $\mathrm{Zn}$ in different plant parts.

Effect of chelator types, rates and their interaction on $\mathrm{Pb}$ concentrations $\left(\mathrm{mg} \mathrm{kg}^{-1} \mathrm{DW}\right)$ of indian mustard plant:

It is worthy to mention that there were not any perceptible concentrations of $\mathrm{Pb}$ in different plant parts except for roots. These findings are in agreement with that of Padmavathiamma and $\mathrm{Li}$ (2007) who reported that $\mathrm{Pb}$ translocation from roots to above-ground parts is very poor. The major proportion of $\mathrm{Pb}$ is concentrated in root tissues. Only $3 \%$ of roots $\mathrm{Pb}$ are translocated to shoots(Zimdahl, 1975). The utmost roots $\mathrm{Pb}$ is deposited, especially as $\mathrm{Pb}$-pyrophosphate, along the cell walls as reported by Meyers et al., (2008).

Fig (2) shows the effect of chelator types, rates and their interaction on $\mathrm{Pb}$ concentrations of indian mustard roots. The results prove that $\mathrm{Pb}$ concentrations in roots was affected by chelator types used in this study, where EDTA and $\mathrm{CA}$ increased $\mathrm{Pb}$ concentrations in roots as compared to HA treatment by $57.74 \%$ and $4.45 \%$, respectively.

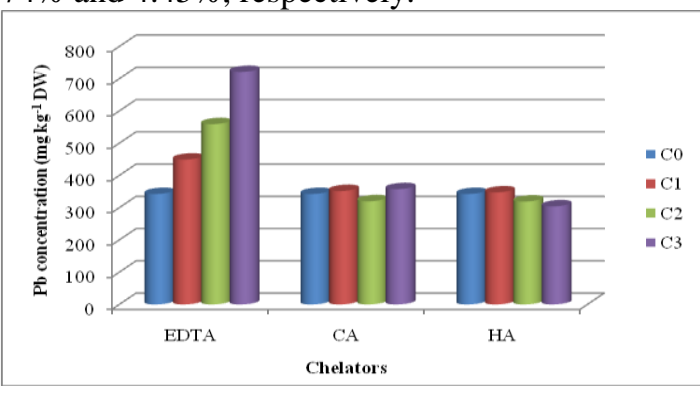

Fig 2. Effect of chelators and their application levels on $\mathrm{Pb}$ concentration $\left(\mathrm{mg} \mathrm{kg}^{-1} \mathrm{DW}\right)$ in indian mustard roots.
Raising EDTA levels up to the highest level used (4.5 mmol $\mathrm{kg}^{-1}$ soil) significantly increased $\mathrm{Pb}$ concentrations in plant roots by 2.10 folds than that of control. Similarly, raising CA levels up to $9 \mathrm{mmol} \mathrm{kg}^{-1}$ soil increased $\mathrm{Pb}$ concentration in roots as compared to control by $4.38 \%$, but this increase was insignificant. These results are in a similar trend with those of Freitas et al., (2013). They outlined that usage of CA at $40 \mathrm{mmol} \mathrm{kg}^{-1}$ soil was effective in the $\mathrm{Pb}$ solubilization of the soil and in the induction of $\mathrm{Pb}$ absorption by Maize (Zea mays) and vetiver (Chrysopogon zizanoides).

On the other hand, no significant effect on $\mathrm{Pb}$ concentration in roots was found due to increasing HA application level to the soil. A slight decrease in $\mathrm{Pb}$ concentrations in roots was found with increasing HA rates. These results are in harmony with those of Wang et al., (2010). They stated that HA clearly reduced $\mathrm{Cu}$ and $\mathrm{Cd}$ bioavailability and toxicity in V. speralis due to forming complexes of HA with metal ions.

Leaching of $\mathrm{Cu}, \mathrm{Zn}$ and $\mathrm{Pb}$ metals $\left(\mathrm{mg}\right.$ pot $^{-1}$ ) under indian mustard cultivation:

Data in Table (5) illustrate the effect of chelator types, their addition rates and their interaction on $\mathrm{Cu}$, $\mathrm{Zn}$ and $\mathrm{Pb}$ leaching $\left(\mathrm{mg} \mathrm{pot}^{-1}\right)$ under indian mustard cultivation in Al-Gabal Al-Asfar soil.

Chelate types significantly affected the leached amount of $\mathrm{Cu}, \mathrm{Zn}$ and $\mathrm{Pb}$ under indian mustard cultivation. Where, EDTA had up normal effect on $\mathrm{Cu}$ and $\mathrm{Zn}$ leaching. The leached amounts due to EDTA application were many times higher than that of CA and HA. In this respect, Application of EDTA treatment increased $\mathrm{Cu}, \mathrm{Zn}$ and $\mathrm{Pb}$ leaching than that of $\mathrm{HA}$ treatment by $26.14,17.54$ and 26.33 folds. Whilst, using $\mathrm{CA}$ increased $\mathrm{Cu}, \mathrm{Zn}$ and $\mathrm{Pb}$ leaching than that of $\mathrm{HA}$ treatment by $2.14,2.88$ and 1.11 folds. These results are in agreement with those of Nascimento et al., (2006) who compared synthetic chelates (EDTA and DTPA) with LMWOA (oxalic acid, citric acid, vanillic acid and gallic acid) in enhancing heavy metals phytoextraction by indian mustard from multi-metal contaminated soils. They reported that the effectiveness of LMWOA were not accompanied by raising the risk of leaching for these metals so unlike EDTA and DTPA.

Concerning chelator levels effect on leached studied metals, increasing EDTA level up to $4.5 \mathrm{mmol}$ $\mathrm{kg}^{-1}$ soil linearly increased the leached $\mathrm{Cu}, \mathrm{Zn}$ and $\mathrm{Pb}$ $\left(\mathrm{mg} \operatorname{pot}^{-1}\right)$ as compared to the control by $58.29,38.36$ and 62.89 folds, respectively.

Likewise EDTA, application of CA up to $9 \mathrm{mmol}$ $\mathrm{kg}^{-1}$ soil significantly increased $\mathrm{Cu}$ and $\mathrm{Zn}$ leaching under indian mustard cultivation, while, non-significant effect regarding to $\mathrm{Pb}$ leaching increase. Application of 9 mmol CA kg ${ }^{-1}$ soil increased leached $\mathrm{Cu}, \mathrm{Zn}$ and $\mathrm{Pb}$ $\left(\mathrm{mg} \mathrm{pot}^{-1}\right)$ by $4.14,6.20$ and 1.22 folds, respectively, compared with control. Contradictory, application of HA different levels did not reveal any significant effect on leaching of tested metals.

Concerning chelator type - rates interaction effects on leached $\mathrm{Cu}, \mathrm{Zn}$ and $\mathrm{Pb}$, highly significant effect was found on these metals leaching ( $\mathrm{mg} \mathrm{pot}^{-1}$ ) under indian mustard cultivation. Where, the highest 
values of leached $\mathrm{Cu}, \mathrm{Zn}$ and $\mathrm{Pb}$ were obtained using EDTA at a level of $4.5 \mathrm{mmol} \mathrm{kg}^{-1}$ soil. So, application of higher level of EDTA to the soil is an inappropriate for use in phytoextraction due to its environmental impact on groundwater contamination via metal

Table 5. Effect of chelator types, rates and their interaction on $\mathrm{Cu}, \mathrm{Zn}$ and $\mathrm{Pb}$ leaching $\left(\mathrm{mg} \mathrm{pot}^{-1}\right)$ under $^{-1}$ indian mustard cultivation.

\begin{tabular}{|c|c|c|c|c|}
\hline \multirow{2}{*}{\multicolumn{2}{|c|}{ Treatments }} & \multicolumn{3}{|c|}{ Metal leaching $\left(\mathrm{mg} \mathrm{pot}^{-1}\right)$} \\
\hline & & $\mathbf{C u}$ & $\mathbf{Z n}$ & $\mathbf{P b}$ \\
\hline & 0 & 0.7 & 5.5 & 0.9 \\
\hline EDTA mmol kg ${ }^{-1}$ & 1.5 & 7.0 & 57.1 & 8.1 \\
\hline \multirow[t]{2}{*}{ soil } & 3.0 & 24.6 & 119.2 & 29.1 \\
\hline & 4.5 & 40.8 & 211.0 & 56.6 \\
\hline \multicolumn{2}{|l|}{ Mean } & 18.3 & 98.2 & 23.7 \\
\hline \multicolumn{2}{|l|}{ F-test } & $* *$ & $* *$ & $* *$ \\
\hline \multicolumn{2}{|l|}{$\mathrm{LSD}_{0.05}$} & 3.9 & 17.6 & 1.4 \\
\hline \multicolumn{2}{|l|}{$\mathrm{LSD}_{0.01}$} & 6.0 & 27.4 & 2.2 \\
\hline \multirow{4}{*}{ CA mmol kg ${ }^{-1}$ soil } & 0 & 0.7 & 5.5 & 0.9 \\
\hline & 3.0 & 0.8 & 9.3 & 1.0 \\
\hline & 6.0 & 1.4 & 15.4 & 1.0 \\
\hline & 9.0 & 2.9 & 34.1 & 1.1 \\
\hline \multicolumn{2}{|l|}{ Mean } & 1.5 & 16.1 & 1.0 \\
\hline \multicolumn{2}{|l|}{ F-test } & $* *$ & $* *$ & $\mathrm{~ns}$ \\
\hline \multicolumn{2}{|l|}{$\mathrm{LSD}_{0.05}$} & 0.5 & 6.7 & \\
\hline \multicolumn{2}{|l|}{$\mathrm{LSD}_{0.01}$} & 0.7 & 10.4 & \\
\hline & 0 & 0.7 & 5.5 & 0.9 \\
\hline \multirow{3}{*}{$\mathrm{HA} \mathrm{g} \mathrm{kg}{ }^{-1}$ soil } & 0.2 & 0.7 & 5.4 & 0.9 \\
\hline & 0.4 & 0.6 & 5.3 & 0.9 \\
\hline & 0.6 & 0.6 & 6.0 & 1.0 \\
\hline \multicolumn{2}{|l|}{ Mean } & 0.7 & 5.6 & 0.9 \\
\hline \multicolumn{2}{|l|}{ F-test } & ns & $\mathrm{ns}$ & ns \\
\hline \multicolumn{5}{|l|}{$\mathrm{LSD}_{0.05}$} \\
\hline \multicolumn{5}{|l|}{$\operatorname{LSD}_{0.01}$} \\
\hline \multicolumn{2}{|l|}{ F-test (treatments) } & $* *$ & $* *$ & $* *$ \\
\hline \multicolumn{2}{|l|}{$\mathrm{LSD}_{0.05}$} & 2.1 & 5.5 & 0.2 \\
\hline \multicolumn{2}{|l|}{$\mathrm{LSD}_{0.01}$} & 3.2 & 8.4 & 0.4 \\
\hline \multicolumn{2}{|l|}{ F-test (Interaction) } & $* *$ & $* *$ & $* *$ \\
\hline \multicolumn{2}{|l|}{$\mathrm{LSD}_{0.05}$} & 1.8 & 4.8 & 0.2 \\
\hline \multicolumn{2}{|l|}{$\mathrm{LSD}_{0.01}$} & 2.7 & 7.3 & 0.3 \\
\hline
\end{tabular}

Compared to EDTA, CA had a small effect on metal concentrations in leachate as its effectiveness was not accompanied by increasing the risk of leaching for these metals so unlike EDTA. These results are in agreement with that of Jean-Soro et al., (2012) who revealed that EDTA is more effective in enhancing heavy metals desorption from the soil solid phase. In most cases, the effect of EDTA was many times greater than that of CA.

Application of different HA levels did not affect metal leachabilty under sunflower and indian mustard cultivation in both soils. This result was in agreement with Halim et al., (2003) who signified that while humic substances are potentially useful to increase plantavailability of heavy metals in soil, they concomitantly reduce the environmental mobility of these contaminants.

\section{CONCLUSION}

It can be concluded that EDTA had the highest efficacy on enhancing $\mathrm{Cu}$ and $\mathrm{Zn}$ absorption by indian mustard plants. Application of CA also increased $\mathrm{Cu}$ and $\mathrm{Zn}$ concentrations in indian mustard plant, while HA was only efficient to increase $\mathrm{Zn}$ absorption by indian mustard plant. The high concentrations of $\mathrm{Cu}$ and leaching. These results are in conformity with that of Meers et al., (2005) who revealed that there exists a high binding constant of EDTA for metals $(\mathrm{Pb}, 19.71$; $\mathrm{Zn}, 18.00$ and $\mathrm{Cu}, 20.49$ ), allowing the dissolution of heavy metals.

$\mathrm{Zn}$ in the plant organs due to applying EDTA compared to the other chelators induced toxicity, so reduced the dry matter of these organs.

Using $\mathrm{CA}$ for the phytoremediation of $\mathrm{Cu}$ and $\mathrm{CA}$ and HA for the phytoremediation of $\mathrm{Zn}$ is favorable than EDTA despite the high efficiency of EDTA, due to either its harmful effect of high rates on plant growth or its increment effect of groundwater contamination risk via metal leaching.

Phytoextraction of $\mathrm{Pb}$ was failed even with EDTA, CA and HA chelators addition, where there were neither any perceptible concentrations of $\mathrm{Pb}$ in the above ground portion of indian mustard plant parts.

\section{REFERENCES}

Alkorta, I.; Hernandez-Allica, J.; Becerril, J. M.; Amezaga, I.; Albizu, I. \& Garbisu, C., (2004). 'Recent findings on the phytoremediation of soils contaminated with environmentally toxic heavy metals and metalloids such as zinc, cadmium, lead, and arsenic'. reviews in Environmental Science and Bio-technology, 3: 7190.

Chapman, H. D. \& Pratt, F., (1961). "Methods of Analysis of: Soils, Plants and Water". Calif. Univ., USA. 
Chen, H. \& Cutright, T., (2001). EDTA and HEDTA effects on cadmium, $\mathrm{Cr}$, and $\mathrm{Ni}$ uptake by Helianthus annuus. Chemosphere, 45: 21-28.

Cottenie, A., Verloo, P. M., Kiekens, L., Velghe, G. \& Camerlynck, R, (1982). "Chemical Analysis of Plants and Soils". Lab. Anal and Agrochem., State Univ., Gent Belgium. pp. 63.

Evangelou, M. W. H.; Ebel, M. \& Schaeffer, A., (2006). Evaluation of the effect of small organic acids on phytoextraction of $\mathrm{Cu}$ and $\mathrm{Pb}$ from soil with tobacco Nicotiana tabacum. Chemosphere, 63: 996-1004.

Evangelou, M. W. H.; Ebel, M. \& Schaeffer, A., (2007). Chelate assisted phytoextraction of heavy metals from soil. Effect, mechanism, toxicity, and fate of chelating agents. Chemosphere, 68: 989-1003.

Freitas, E. V.; Nascimento, C. W.; Souza, A. \& Silva, F. B., (2013). Citric acid-assisted phytoextraction of lead: A field experiment. Chemosphere, 92: 213-217.

Hadi, F.; Bano, A.; \& Fuller, M. P., (2010). The improved phytoextraction of lead $(\mathrm{Pb})$ and the growth of maize (Zea mays $L$.): The role of plant growth regulators (GA3 and IAA) and EDTA alone and in combinations. Chemosphere, 80: 457-462.

Halim, M.; Conte, P. \& Piccolo, A., (2003). Potential availability of heavy metals to phytoextraction from contaminated soils induced by exogenous humic substances. Chemosphere, 52(1): 265-75.

Hesse, P. R., (1971). "A Text book of Soil Chemical Analysis". John Murray Ltd, London, pp. 520.

Hofrichter, M. \& Steinbüchel, A., (2001). Biopolymers, vol. 1, Lignin, Humic Substances and Coal. Wiley Europe-VCH, Weinheim, New York.

Jackson, M. L. (1973). "Soil Chemical Analysis". Prentice Hall of Englewood cliffs, New Jersey, USA.

Jean-Soro, L.; Bordas, F. \& Bollinger, J. C., (2012). Column leaching of chromium and nickel from a contaminated soil using EDTA and citric acid. Environ. Pollut., 164: 175-181.

Lindsay, W. L. \& Norvell, W. A., (1978). Development of DTPA soil test for zinc, iron, manganese and copper. Soil, Sci. Soc. Am. J., 42:421-428.

Mahjoub, O., (2016). Wastewater use in agriculture and relevance of micropollutants in North African countries. In: Fatta-Kassinos, D., Dionysiou, D. D. \&Kümmerer, K. (Editors). Wastewater Reuse and Current Challenges. 44: 193-212.

Meers, E.; Ruttens, A.; Hopgood, M.; Lesage, E. \& Tack, F. M. G., (2005). Potential of Brassica rapa, Cannabis sativa, Helianthus annuus and Zea mays for phytoextraction of heavy metals from calcareous dredged sediment derived soils. Chemosphere, 61: $561-572$

Meyers, D. E. R.; Auchterlonie, G. J.; Webb, R. I. \& Wood, B., (2008). Uptake and localisation of lead in the root sytem of indian mustard. Environ. Pollut., 153:323332.

Najeeb, U.; Jilani, G.; Ali, S.; Sarwar, M.; Xu, L. \& Zhou, W. J., (2011). Insight into cadmium induced physiological and ultrastructural disorders in Juncus effusus $L$. and its remediation through hexogenous citric acid. J. Hazard. Mater., 186: 565-574.
Najeeb, U.; Xua, L.; Ali, S.; Jilani, G.; Gonga, H. J.; Shenc, W. Q. \& Zhou, W. J., (2009). Citric acid enhances the phytoextraction of manganese and plant growth by alleviating the ultrastructural damages in Juncus effusus L. J.Hazard.Mater., 170: 1156-1163.

Nascimento, C. W. A.; Amarasiriwardena, D. \& Xing, B., (2006). Comparison of natural organic acids and synthetic chelates at enhancing phytoextraction of metals from a multi-metal contaminated soil. Environ. Poll., 140: 114-123.

Nigam, R.; Srivastava, S.; Prakash, S. \& Srivastava, M. M., (2001). Cadmium mobilisation and plant availability - the impact of organic acids commonly exuded from roots. Plant Soil, 230: 107-113.

Padmavathiamma, P. K. \& Li, L. Y., (2007). Phytoremediation technology: hyperaccumulation metals in plants. Water Air Soil Pollut., 184: 105-126.

Page, A. L., (ed.) (1982). "Methods of Soil Analysis", part 2: Chemical and Microbiological Properties, (2 ${ }^{\text {nd }} E d$.) American Society at Agronomy, Inc. Soil. Sci Soc. Of Am. Inc., Madison. Wisconsin, USA.

Piper, C. S., (1950)."Soil and Plant Analysis", Interscience Publishing Inc. New York.

Richards, L. A., (Ed) (1954). "Diagnosis and Improvement of Saline and Alkali Soils". U. S. Salinity laboratory staff. Agric. Handbook No. 60, Washington, D. C. USA.

Robinson, B. H.; Banuelos, G.; Conesa, H. M.; Evangelon, W. H. \& Schulin, R., (2009). The phytomanagement of trace elements in soil. Crit. Rev. Plant Sci., 28 (4), 240-266.

Shahid, M; Pinelli, E. \& Dumat, C., (2012). Review of Pb availability and toxicity to plants in relation with metal speciation: Role of synthetic and natural organic ligands. J. Hazard. Mater., 219-220, 1-12.

Snedecor, G. W. and W. G. Cochran, (1980)."Statistical Methods", Seventh ed. The Iowa State Univ. Press, Ames. Iowa, USA, pp. 1-507.

Taalab, A. S.; Zaghloul, B. M. \& Gérard, F., (2009). Effect of synthetic chelators and low molecular weight organic acid in enhancing uptake of lead and nickel by mustard (Sinapis Alba L.). Egypt. J. Soil Sci., 49(2): 203-214.

Topcuoğlu, B., (2012). The influence of humic acids on the metal bioavailability and phytoextraction efficiency in long-term sludge applied soil. Conference on International Research on Food Security, Natural Resource Management and Rural Development. Georg-August Universität Göttingen and University of Kassel-Witzenhausen. Göttingen, Germany, September 19-21.

Turan, M., \& Angin, I. (2004). Organic chelate assisted phytoextraction of $\mathrm{B}, \mathrm{Cd}, \mathrm{Mo}$ and $\mathrm{Pb}$ from contaminated soils using two agricultural crop species. Acta Agriculturæ Scandinavica Section B, Soil and Plant Science, 54: 221-231.

Wang, Q.; Li, Z.; Cheng, S. \& Wu, Z., (2010). Influence of humic acids on the accumulation of copper and cadmium in Vallisneria spiralis $L$. from sediment. Environ Earth Sci., 61: 1207-1213.

Wu, L. H.; Luo, Y. M.; Christie, P. \& Wong, M. H., (2003). Effects of EDTA and low molecular weight organic acids on soil solution properties of a heavy metal polluted soil. Chemosphere, 50: 819-822. 
Wu, L. H.; Luo, Y. M.; Xing, X. R. \& Christie, P., (2004). EDTA-enhanced phytoremediation of heavy metal contaminated soil with indian mustard and associated potential leaching risk. Agr. Ecosyst. Environ., 102: 307-318.

Zaheer, I. E.; Ali, S.; Rizwan, M.; Farid, M.; Shakoor, M. B.; Gill, R. A.; Najeeb, U.; Iqbal, N. \& Ahmad, R., (2015). Citric acid assisted phytoremediation of copper by Brassica napus L. Ecotoxicology and Environmental Safety, 120: 310-317.
Zhang, X.; Ervin, E. H., \& Schmidt, R. E. (2003). Plant growth regulators can enhance the recovery of Kentucky bluegrass sod from heat injury. Crop Science, 43: 952-956.

Zimdahl, R. L., (1975). Entry and movement in vegetation of lead derived from air and soil sources. paper presented at $68^{\text {th }}$ Annu. Meeting of the Air Pollution Control Association, Boston, MA, June 15, 2, 1975.

تأثير الإديتا وحامض الستريك وحامض الهيوميك على عملية التخلص من العناصر الثقيلة بواسطة نباتات الخردل

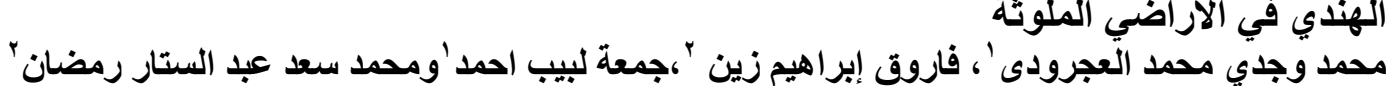

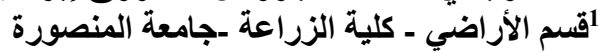
2معهد بحوث الأراضي والمياه والبيئة مركز البحوث الزئية الزراعية

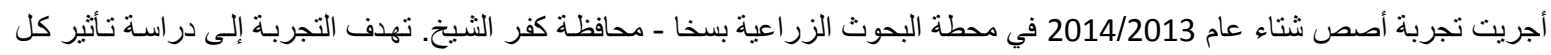

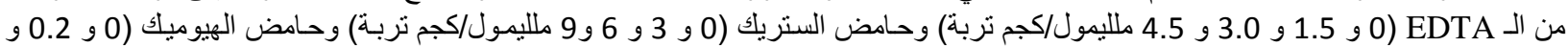

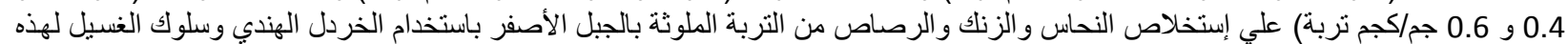

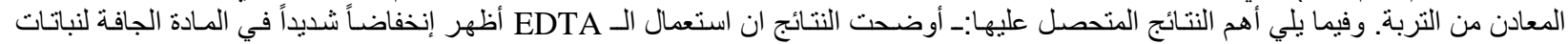

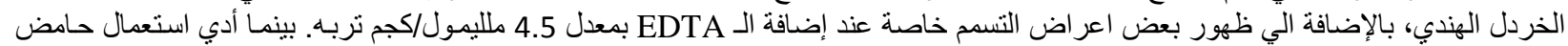

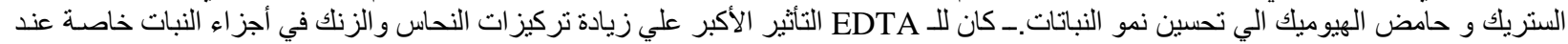

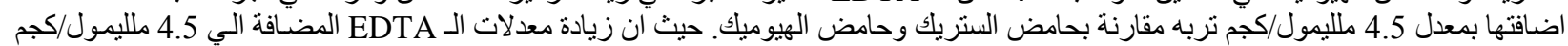

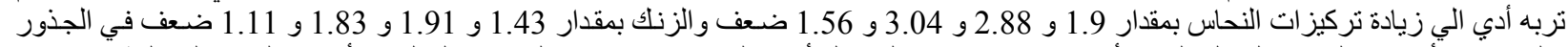

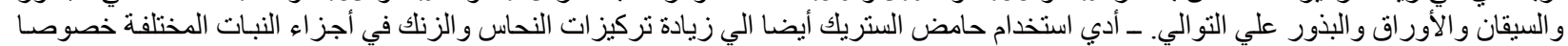

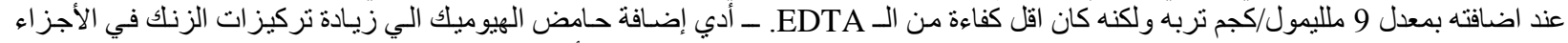

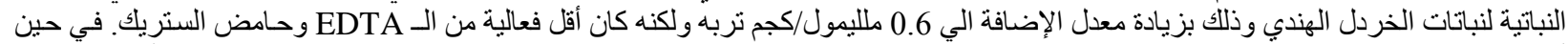

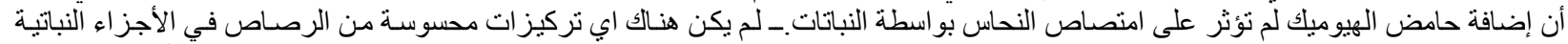

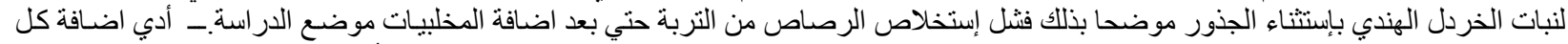

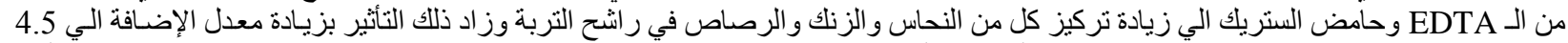

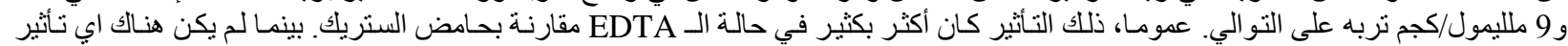

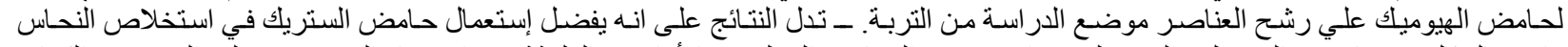

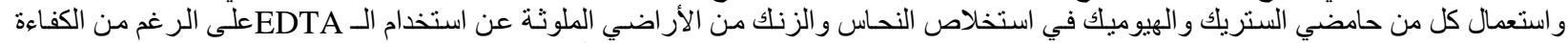

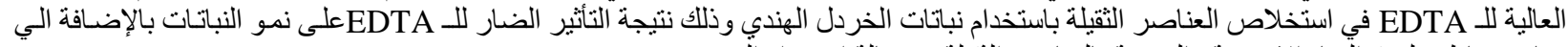
زيادة مخاطر تلوث المياه الارضية والجوفية بالعناصر الثقبلة في حالة استخدام الـ EDTA. 